Article

\title{
Fabrication of a Flexible Micro Temperature Sensor for Micro Reformer Applications
}

\author{
Chi-Yuan Lee *, Chien-Hen Lin and Yi-Man Lo
}

Department of Mechanical Engineering, Yuan Ze Fuel Cell Center, Yuan Ze University, Taoyuan, Taiwan; E-Mails: s911415@mail.yzu.edu.tw (C.-H.L.); s995048@mail.yzu.edu.tw (Y.-M.L.)

* Author to whom correspondence should be addressed; E-Mail: cylee@saturn.yzu.edu.tw; Tel.: +886-3-4638800 ext. 2478; Fax: +886-3-4558013.

Received: 24 February 2011; in revised form: 18 March 2011 / Accepted: 25 March 2011 / Published: 25 March 2011

\begin{abstract}
Micro reformers still face obstacles in minimizing their size, decreasing the concentration of $\mathrm{CO}$, conversion efficiency and the feasibility of integrated fabrication with fuel cells. By using a micro temperature sensor fabricated on a stainless steel-based micro reformer, this work attempts to measure the inner temperature and increase the conversion efficiency. Micro temperature sensors on a stainless steel substrate are fabricated using micro-electro-mechanical systems (MEMS) and then placed separately inside the micro reformer. Micro temperature sensors are characterized by their higher accuracy and sensitivity than those of a conventional thermocouple. To the best of our knowledge, micro temperature sensors have not been embedded before in micro reformers and commercial products, therefore, this work presents a novel approach to integrating micro temperature sensors in a stainless steel-based micro reformer in order to evaluate inner local temperature distributions and enhance reformer performance.
\end{abstract}

Keywords: MEMS; flexible micro temperature sensor; micro reformer

\section{Introduction}

Proton exchange membrane fuel cells (PEMFCs) use hydrogen and oxygen as fuel. In this process, oxygen can be produced from the atmosphere, and hydrogen can be produced from fossil fuels. The 
main processes involved are steam reforming, partial oxidation and coal gasification. Hydrogen can also be produced from non-fossil fuels, in which the main processes are water splitting, photoelectrochemical water splitting [1,2] and a few of other methods. Reformers are extensively used in fuel cells due to ease in obtaining fossil fuels and the large amount of hydrogen available after reforming.

Methanol is a more attractive liquid fuel for use in a proton exchange membrane fuel cell due to its high degree of safety in terms of storage and portability, high carbon/hydrogen ratio, high power density and low temperature reforming capability $\left(250 \sim 300{ }^{\circ} \mathrm{C}\right)$ [3]. However, depending on the available technology, persistent problems on the application side include the starting time, power density, and difficulty in producing hydrogen efficiently and continuously.

A flexible electrical element differs from a traditional one in that the latter uses silicon and glass as the base material, and is more fragile and prohibitively expensive. Conversely, a flexible micro electric element fabricated on thin metal foil or a high polymer is inexpensive, lightweight, shockproof and shatterproof. Due to its high mobility, a flexible electrical element can be used in different electrical product shapes and has a wide range of applications.

By using a resistance type micro temperature sensor, this work monitors the inner temperature of a micro reformer and uses physical vapor deposition to deposit $\mathrm{Au}$ for use as a sensitive metal. Additionally, by using a thin metal foil as the base material of a micro sensor, this work attempts to decrease the interference of a methanol reformer and diagnose the inner environment immediately. Liu and Yang used polyimide as the base material [4,5], while Chuang fabricated a micro temperature sensor and micro heater on a PDMS film [6]. This work fabricated the micro temperature sensor on stainless steel foil, which has been used successfully by the authors in previous works [7]. The advantages of stainless steel are: (1) it has better chemical resistance than other metals (non-noble metals); (2) high mechanical strength, it can be placed and operated in a high temperature and high pressure environment; (3) good heat conductivity and electric conductivity. The properties of stainless steel are listed in Table 1.

Table 1. The properties of stainless steel.

\begin{tabular}{|l|c|}
\hline Specific gravity & 8.03 \\
Coefficient of linear expansion $\left(\times 10^{-6} /{ }^{\circ} \mathrm{C}\right)$ & $18.7 / 0 \sim 650{ }^{\circ} \mathrm{C}$ \\
Thermal conductivity $\left(\mathrm{W} / \mathrm{m}^{\circ} \mathrm{C}\right)$ & 16.3 \\
Specific heat $\left(\times 10^{3} \mathrm{~J} / \mathrm{kg}^{\circ} \mathrm{C}\right)$ & 0.5 \\
Hardness $(\mathrm{HV})$ & $\leq 200$ \\
\hline
\end{tabular}

Garcia-Alonso [8] fabricated a thin film high pressure sensor on a stainless steel substrate with a $\mathrm{SiO}_{2}$ insulator interlayer; the process included a precipitation heat treatment, polishing and cleaning processes, and a chemical surface preparation.

Chang [9] integrated a capacitive pressure sensor on a stainless steel substrate, whereby a stainless steel sheet $(12.7 \mu \mathrm{m})$ with a surface roughness of $100 \AA$ and a titanium film $(25.4 \mu \mathrm{m})$ with a surface roughness of $60 \AA$ are laminated on the stainless steel substrate using a hot press. 
Jiang [10-13] fabricated an array temperature sensor on a flow plate to measure the temperature distribution. The sensor in this example was made of silicon, is much thicker than stainless steel, and it is not flexible, thus, in our work we fabricated the sensor with stainless steel.

Shih fabricated a platinum thin film micro temperature sensor on a chip and then combined it with complementary metal-oxide semiconductor (CMOS). The measurement ranged from $25{ }^{\circ} \mathrm{C}$ to $65{ }^{\circ} \mathrm{C}$, resistance ranged from $11.9 \sim 12.7 \mathrm{~K} \Omega$, and the sensitivity was $1.68 \mathrm{~K} \Omega /{ }^{\circ} \mathrm{C}$ [14]. In our work, we have obtained a better and wider temperature measurement range from $30{ }^{\circ} \mathrm{C}$ to $280{ }^{\circ} \mathrm{C}$.

Xiao [15] developed an economic and flexible micro temperature sensor by first using low pressure chemical vapor deposition to deposit phosphosilicate glass to be the sacrificial layer. A layer of polyimide was then coated, followed by use of MEMS technology to layer platinum on the polyimide, making the sensor flexible. Finally, the sacrificial layer was removed, by which the position of the sensor was not limited.

Using polyamide foil as the basic material, Bielska [16] fabricated a gold and copper electrode on it via MEMS technology. The temperature ranged from $30{ }^{\circ} \mathrm{C}-42{ }^{\circ} \mathrm{C}$, and the resistance change according to the temperature was used to study its linear performance.

Although micro temperature sensors have been used in numerous areas, for example, fuel cells, lithium batteries, etc., they have not been embedded yet in micro reformers and commercial products. This work describes the fabrication of micro temperature sensors on stainless steel foil using MEMS technology. The proposed fabrication approach is characterized by its compact size, flexible yet precise measurement positions, mass production capability, usability in high-temperature $\left(>300{ }^{\circ} \mathrm{C}\right)$ environments, as well as high corrosion resistance and high compression resistance, capable of withstanding the operating environment of a micro reformer. Because the conversion efficiency increases with the temperature, thus, by monitoring the inner temperature, we can change the water/methanol ratio and fuel supply rate immediately, and increase or maintain the conversion efficiency as desired.

\section{Methodology}

In this work, a resistance temperature detector (RTD) was used as the temperature sensor. As a metal conductor with a positive temperature coefficient (PTC), the resistance of an RTD increases with an increasing environmental temperature. A situation in which the temperature variation of an RTD is linear suggests that the relationship between measured resistance and temperature change can be expressed as follows:

$$
\begin{gathered}
R_{t}=R_{r}\left(1+\alpha_{T} \Delta T\right) \\
\Delta T=t-t_{r}
\end{gathered}
$$

where $R_{t}$ and $R_{r}$ denote the resistances of an RTD at $t^{\circ} \mathrm{C}$ and $r{ }^{\circ} \mathrm{C}$, respectively; $\alpha_{T}$ denotes the positive temperature coefficient of RTD; $\Delta T$ represents the variation in a temperature relative to the reference temperature; and $t$ and $t_{r}$ refer to the RTD temperatures at $t^{\circ} \mathrm{C}$ and $r{ }^{\circ} \mathrm{C}$, respectively. Equation (2) can thus be rewritten as:

$$
\alpha_{T}=\frac{R_{t}-R_{r}}{R_{r}(\Delta T)}
$$


where $\alpha_{T}$ denotes the sensitivity of a temperature sensor $\left(1 /{ }^{\circ} \mathrm{C}\right)$ [17]. This micro temperature sensor is used hereinafter in the micro reformer.

\section{Fabrication of Flexible Micro Temperature Sensors}

Figure 1 illustrates diagrammatically the flexible micro temperature sensor fabrication process. Because of its low cost, stainless steel was chosen as the substrate. The micro temperature sensor is composed of gold. A layer of aluminum nitride (AIN) must be sputtered as an isolating insulation layer, regardless of whether wet etching or lift-off is used. AlN was adopted as an insulation layer, since it has excellent insulating and high thermally conductive properties [18]. Consequently, in this work, $10,000 \AA$ of AlN is sputtered. Since AlN is readily etched by MP2500 developer, the pattern is defined using an etching method. Figure 2 shows the linearity of gold compared with platinum; although platinum has better linearity than gold, gold still shows a good linearity at the reformer operating temperature (below $300{ }^{\circ} \mathrm{C}$ ); Table 2 shows the resistivity of gold compared with other metals, and we can see that gold has the second highest resistivity [19]. Although platinum seems better than gold, it costs much more and one has to use lift-off, which is harder to control accurately, to define the pattern. Thus, gold was adopted as the sensing material.

Figure 1. Flowchart of the micro temperature sensor assembly.

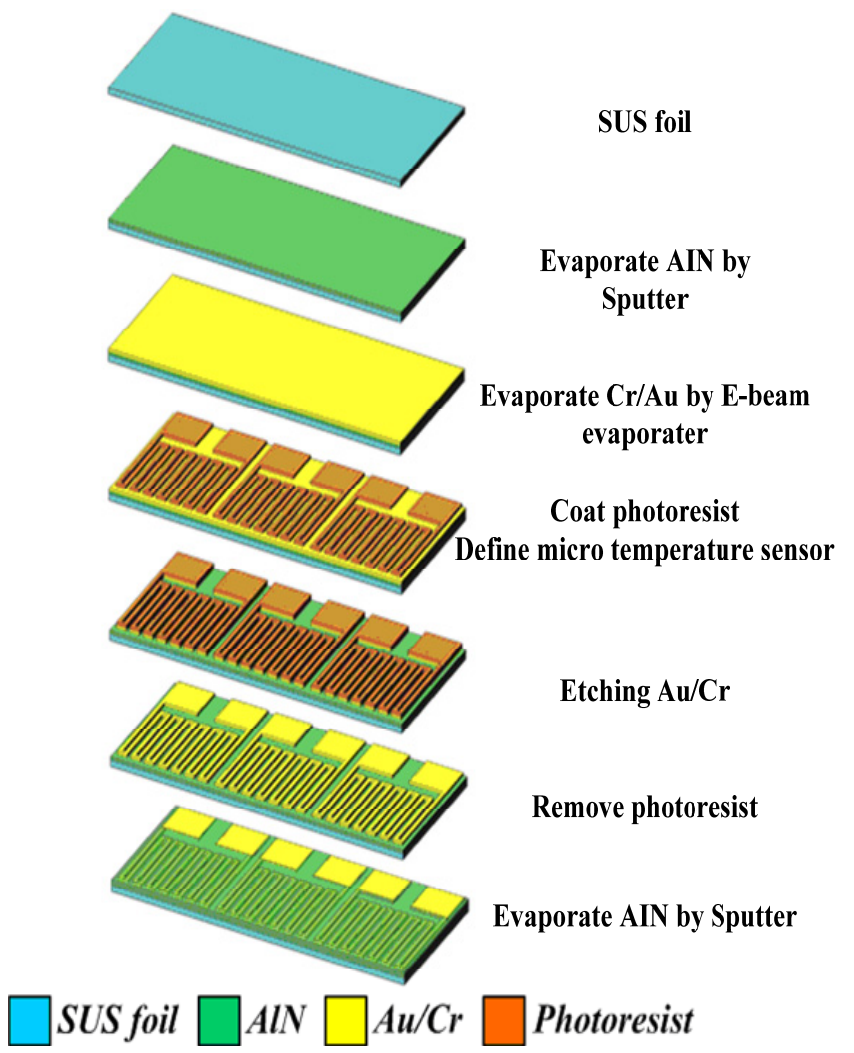


Figure 2. The linearity comparison of sensing materials [19,20].

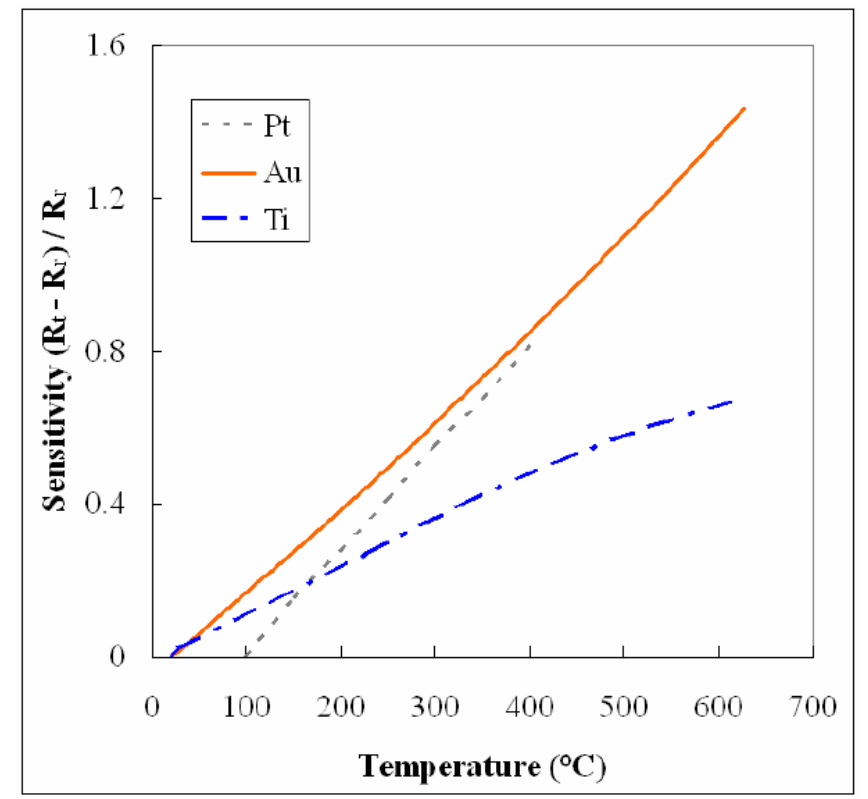

Table 2. Compared resistivity of metals [21].

\begin{tabular}{|c|c|c|c|}
\hline Material & $\begin{array}{c}\boldsymbol{\rho} \\
(\boldsymbol{\mu} \boldsymbol{\Omega} \cdot \mathbf{m})\end{array}$ & $\begin{array}{c}\boldsymbol{\alpha}_{\mathbf{T}} \\
\left(\mathbf{p p m} /{ }^{\circ} \mathbf{C}\right)\end{array}$ & $\begin{array}{c}\boldsymbol{\rho} \boldsymbol{\alpha}_{\mathbf{T}} \\
(\mathbf{p} \boldsymbol{\Omega} \cdot \mathbf{m})\end{array}$ \\
$\mathrm{Pt}$ & 0.102 & $3900 \pm 0.9 \%$ & $\sim 400$ \\
$\mathrm{Au}$ & 0.0222 & $3950 \pm 1.3 \%$ & $\sim 90$ \\
$\mathrm{Ag}$ & 0.0155 & $3950 \pm 3.8 \%$ & $\sim 60$ \\
$\mathrm{Cu}$ & 0.0157 & $4200 \pm 2.4 \%$ & $\sim 70$ \\
\hline
\end{tabular}

Initially, chromium ( $\mathrm{Cr}, 400 \AA$ ) was evaporated as a sticking layer by an E-beam evaporator, followed by evaporation of $2,000 \AA$ of gold. Next, the pattern of a micro temperature sensor is defined by photolithography, followed by etching of chromium and gold. Finally, the photoresist is removed with acetone. Figure 3 displays the micro temperature sensor. The details of the fabrication parameters are shown in Table 3.

Figure 3. Optical microscopy image of a micro temperature sensor.

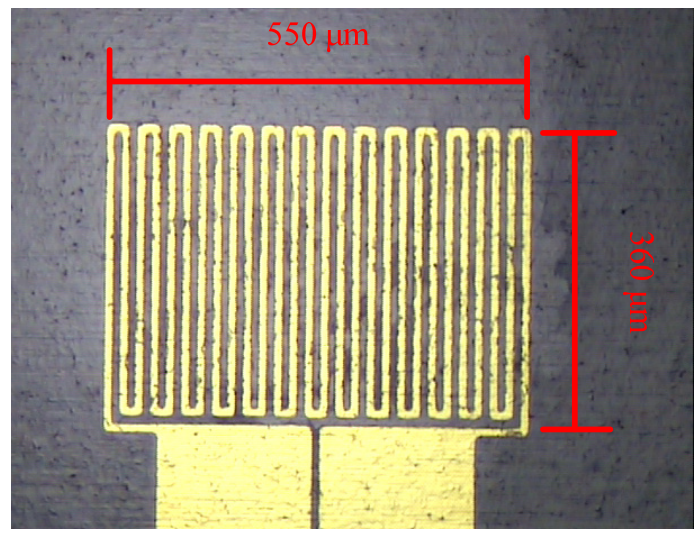


Table 3. Fabrication parameters of micro temperature sensors.

\begin{tabular}{|c|c|}
\hline Step & Recipe \\
\hline 1 & $\begin{array}{l}\text { Steel foil: stainless steel foil substrate (SS-304 } 40 \mu \mathrm{m} \text { thick) } \\
\mathrm{H}_{2} \mathrm{SO}_{4}+\mathrm{H}_{2} \mathrm{O}_{2} \text { (cleaning } 10 \text { mins) }\end{array}$ \\
\hline 2 & $\begin{array}{l}\text { AlN sputtering: } \\
\operatorname{Ar}(6.8 \mathrm{sccm}), \mathrm{N}_{2}(1.7 \mathrm{sccm}), \text { Pressure }(0.23 \mathrm{~Pa}) \text {, Substrate temperature }\left(120^{\circ} \mathrm{C}\right) \text {, Power }(150 \mathrm{~W})\end{array}$ \\
\hline 3 & $\begin{array}{l}\text { Cr/ Au evaporating: } \\
\text { Substrate temperature }\left(100{ }^{\circ} \mathrm{C}\right) \text {, Background pressure }\left(8 \times 10^{-7} \text { Torr }\right), \mathrm{Cr} \text { thickness }(200 \AA), \mathrm{Au} \\
\text { thickness }(2,000 \AA)\end{array}$ \\
\hline 4 & $\begin{array}{l}\text { Lithography: } \\
\text { Spin coated photoresist }(\text { AZ-4620 }) \rightarrow 6,000 \mathrm{rpm}, 30 \mathrm{~s} . \text { Soft bake } \rightarrow 110{ }^{\circ} \mathrm{C}, 90 \mathrm{~s} . \text { Exposure } \rightarrow 182 \mathrm{~mJ} / \mathrm{cm}^{2} . \\
\text { Development } \rightarrow \text { MP } 2500: \text { DI water }=5: 1, \\
\text { Hard bake } \rightarrow 110^{\circ} \mathrm{C}, 10 \mathrm{mins}\end{array}$ \\
\hline 5 & $\begin{array}{l}\text { Au / Cr etching: } \\
\mathrm{Au} \text { etching }\left(\mathrm{KI}+\mathrm{I}_{2}\right), \mathrm{Cr} \text { etching }(\mathrm{Cr}-7)\end{array}$ \\
\hline 6 & $\begin{array}{l}\text { Lithography: } \\
\text { Spin coated photoresist }\left(\text { AZ-4620) } \rightarrow 6,000 \mathrm{rpm}, 30 \mathrm{~s} . \text { Soft bake } \rightarrow 110^{\circ} \mathrm{C}, 90 \mathrm{~s} \text {. }\right. \\
\text { Exposure } \rightarrow 182 \mathrm{~mJ} / \mathrm{cm}^{2} . \text { Development } \rightarrow \text { MP2500:DI water }=5: 1 \\
\text { Hard bake } \rightarrow 110^{\circ} \mathrm{C}, 10 \text { mins }\end{array}$ \\
\hline 7 & $\begin{array}{l}\text { AlN etching: } \\
\mathrm{H}_{3} \mathrm{PO}_{4}\left(70^{\circ} \mathrm{C}\right)\end{array}$ \\
\hline 8 & $\begin{array}{l}\text { Photoresist (AZ-4620) back coating: } \\
\text { Spin coated photoresist } \rightarrow 1,000 \mathrm{rpm}, 10 \mathrm{~s} . \text { Hard bake } \rightarrow 110^{\circ} \mathrm{C}, 30 \text { mins. }\end{array}$ \\
\hline 9 & $\begin{array}{l}\text { Steel foil etching: } \\
\text { Aqua regia }\left(40^{\circ} \mathrm{C}\right)\end{array}$ \\
\hline 10 & $\begin{array}{l}\text { Define protection layer: } \\
\text { Spin coated photoresist }(\text { AZ-4620 }) \rightarrow 6,000 \mathrm{rpm}, 30 \mathrm{~s} \text {. Soft bake } \rightarrow 110^{\circ} \mathrm{C}, 90 \mathrm{~s} \text {. } \\
\text { Exposure } \rightarrow 182 \mathrm{~mJ} / \mathrm{cm}^{2} . \text { Development } \rightarrow \mathrm{MP} 2500: \text { DI water }=5: 1, \\
\text { Hard bake } \rightarrow 110^{\circ} \mathrm{C}, 30 \text { mins }\end{array}$ \\
\hline
\end{tabular}

\section{Results and Discussion}

The inner resistance of a temperature sensor can be obtained based on the equation relating temperature and resistance, followed by calculation of the temperature inside the reformer by interpolation.

The calibration system is shown in Figure 4. The sensor is first fabricated at the flow plate, and then is put into the drying oven chamber to control the temperature. A NI PXI 1033 unit is used to measure the resistance of the sensor, and then the sensor can be calibrated. The temperature is calibrated from $30{ }^{\circ} \mathrm{C}$ to $280{ }^{\circ} \mathrm{C}$. Figure 5 shows the calibration curve, indicating that the temperature and resistance are linearly dependent on each other. 
Figure 4. Calibration system.

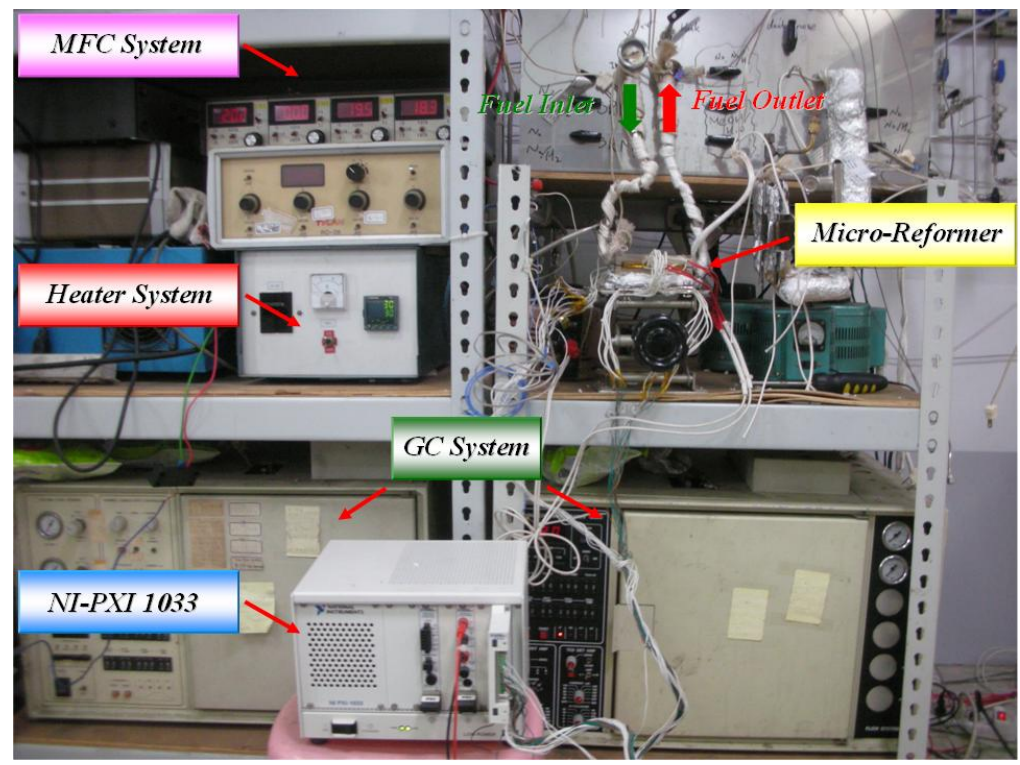

Figure 5. Calibration curves of micro temperature sensors.

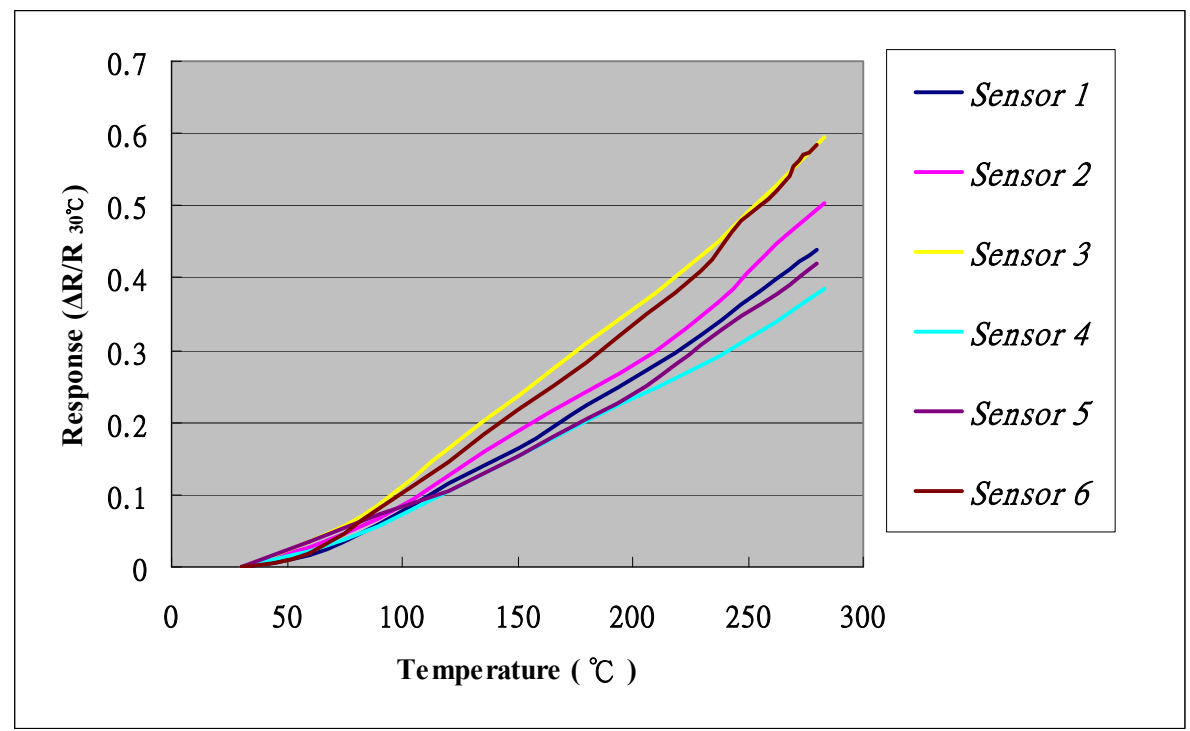

Next, steam reforming of methanol (SRM) was performed with $30 \mathrm{mg}$ of a catalyst, followed by infusion of a mixture of methanol and water $(\mathrm{S} / \mathrm{C}=1.3)$. Following reduction of the catalyst, the temperature is increased from $175{ }^{\circ} \mathrm{C}$ to $250{ }^{\circ} \mathrm{C}$ in $25{ }^{\circ} \mathrm{C}$ intervals, during which the relationship between reaction temperature and methanol conversion is observed. When heating to $250{ }^{\circ} \mathrm{C}$, the methanol conversion is close to $71 \%$. Figure 6 shows the measurement results. Because the conversion efficiency increases with the temperature, thus, by monitoring the inner temperature, we can change the water/methanol ratio and fuel supply rate immediately, and then increase or maintain the conversion efficiency. 
Figure 6. Relative curve of conversion and temperature under the SRM reaction.

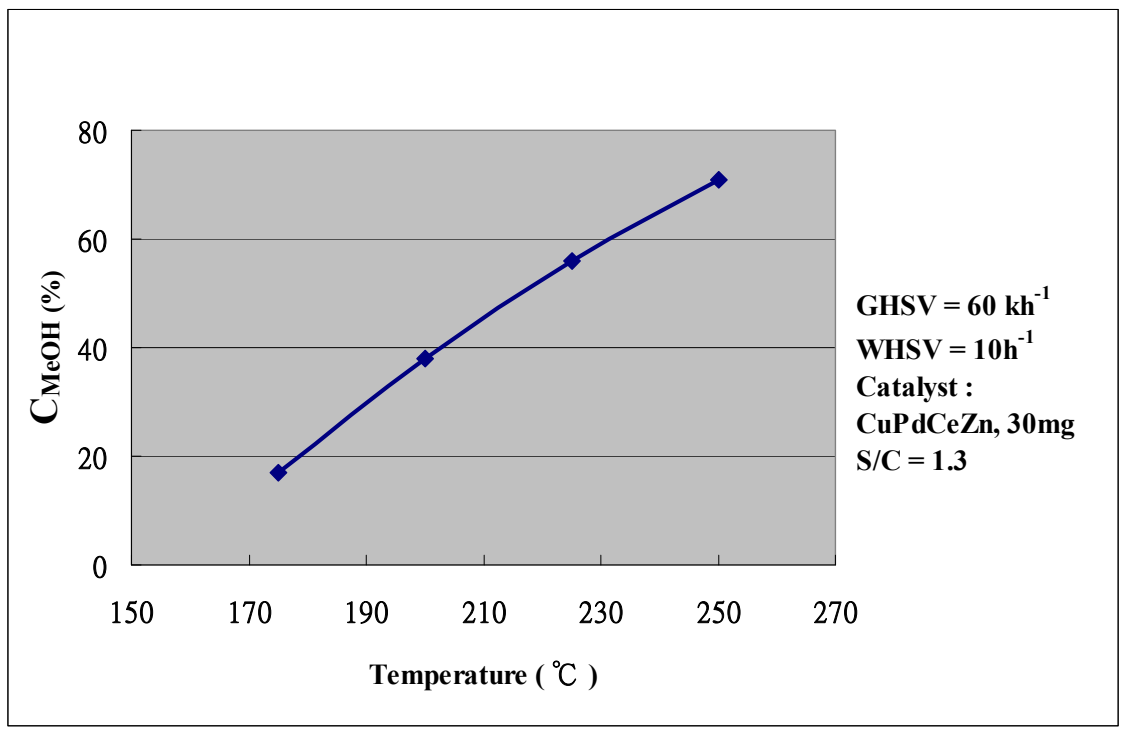

After steady operation of the micro reformer at $250{ }^{\circ} \mathrm{C}$, the NI PXI-1033 system is used to capture the signal of micro temperature sensor every 1.5 seconds, with the fuel supply stopped after 750 seconds to observe the variation in temperature. Figure 7 shows the assigned numbers and location of micro temperature sensors, which has two sensors at each part of the reformer (upstream, midstream and downstream). Consequently, the curve between temperature and time can be obtained, as shown in Figures 8 and 9. Table 4 shows the sensitivity, linearity and initial resistance of the micro temperature sensors.

Figure 7. Distribution of micro temperature sensors during calibration.

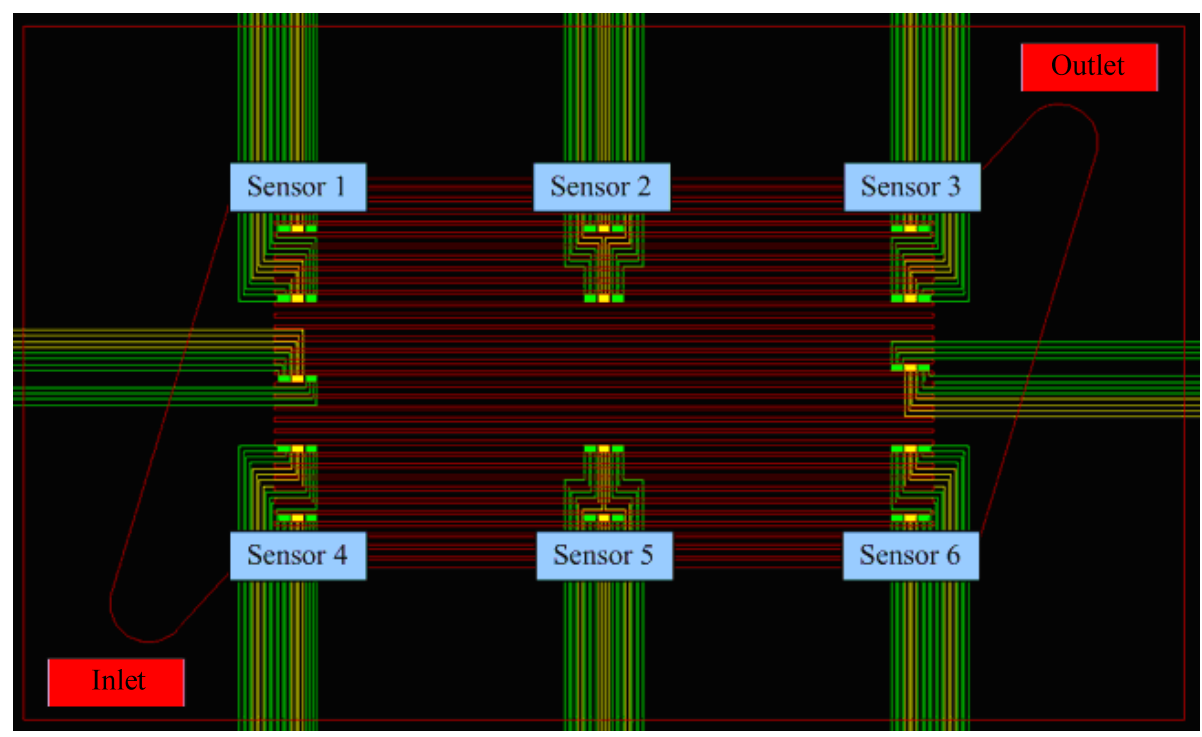


Figure 8. Temperature distribution of micro sensors $1 \sim 3$ insider the reformer.

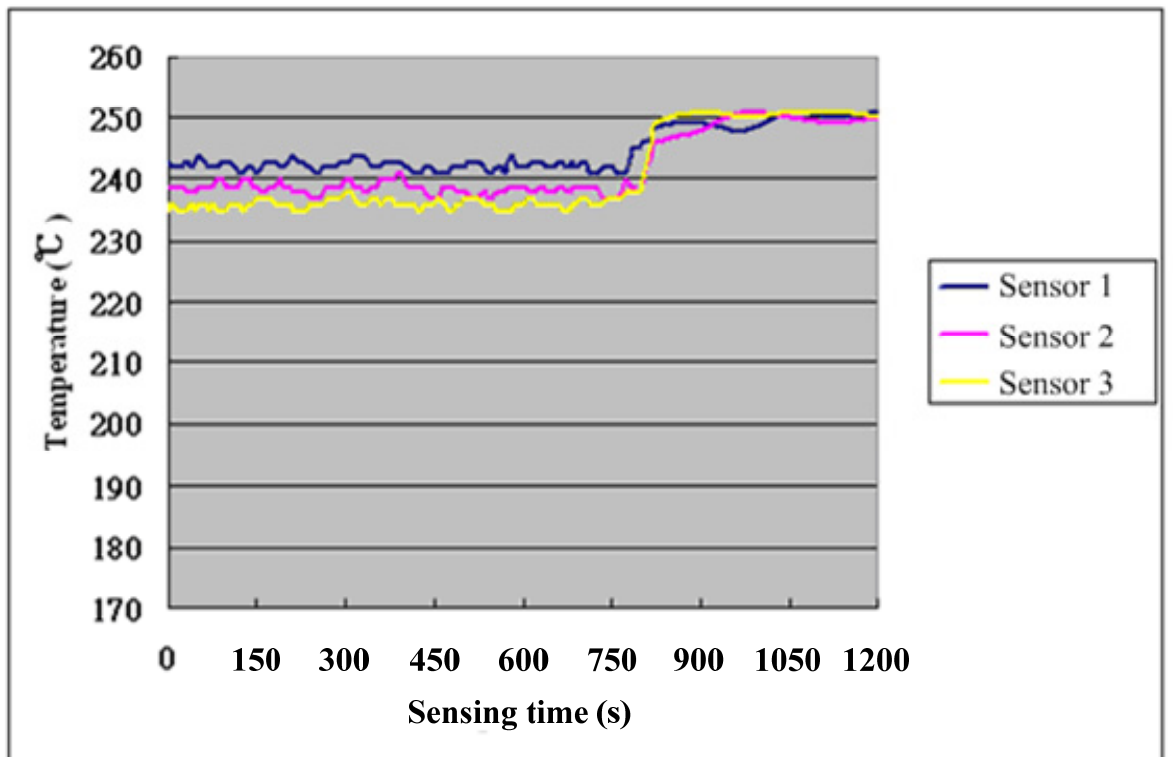

Figure 9. Temperature distribution of micro sensors $4 \sim 6$ insider the reformer.

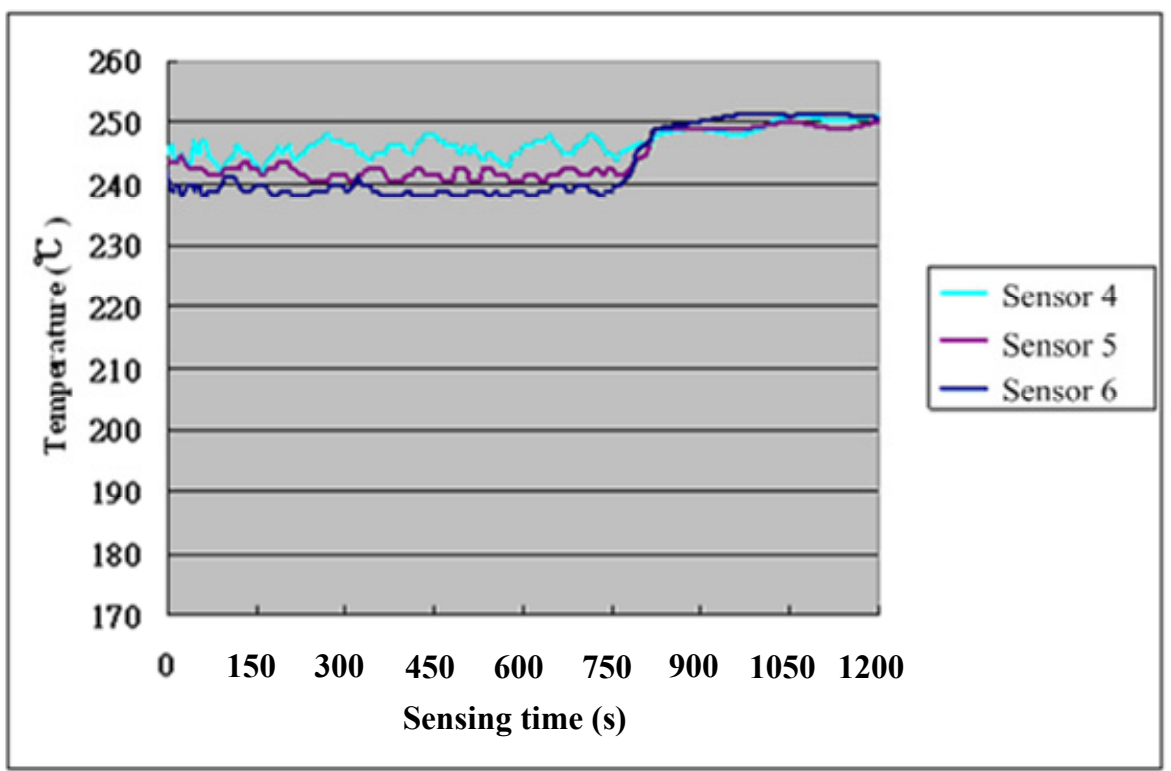

Table 4. Sensitivity of the micro temperature sensors.

\begin{tabular}{|c|c|c|c|}
\hline $\begin{array}{c}\text { Micro } \\
\text { sensors }\end{array}$ & Sensitivity & Linearity & $\begin{array}{c}\text { Initial } \\
\text { resistance }\end{array}$ \\
\hline Sensor 1 & $1.8270 \times 10^{-3} /{ }^{\circ} \mathrm{C}$ & 0.993826146 & $517 \Omega$ \\
Sensor 2 & $1.9949 \times 10^{-3} /{ }^{\circ} \mathrm{C}$ & 0.991182651 & $514 \Omega$ \\
Sensor 3 & $2.3536 \times 10^{-3} /{ }^{\circ} \mathrm{C}$ & 0.995711337 & $478.9 \Omega$ \\
Sensor 4 & $1.5261 \times 10^{-3} /{ }^{\circ} \mathrm{C}$ & 0.995731697 & $648 \Omega$ \\
Sensor 5 & $1.8181 \times 10^{-3} /{ }^{\circ} \mathrm{C}$ & 0.991984453 & $612 \Omega$ \\
Sensor 6 & $2.4074 \times 10^{-3} /{ }^{\circ} \mathrm{C}$ & 0.992921296 & $478.8 \Omega$ \\
\hline
\end{tabular}




\section{Conclusions}

This work describes the fabrication, calibration and measurement of a micro temperature sensor. After the catalyst is reduced, the temperature is heated in intervals of $25{ }^{\circ} \mathrm{C}$ from $175{ }^{\circ} \mathrm{C}$ to $250{ }^{\circ} \mathrm{C}$, during which the relationship between reaction temperature and methanol conversion is observed. This work first presents a novel approach to integrating micro temperature sensors in a stainless steel-based micro reformer in order to evaluate inner local temperature distributions. The proposed fabrication approach is characterized by its compact size, flexible yet precise measurement positions, mass production capability, use in high-temperature $\left(>300^{\circ} \mathrm{C}\right)$ environments, as well as high corrosion resistance and high compression resistance, capable of withstanding the operating environment of a micro reformer.

\section{Acknowledgements}

This work was accomplished with much needed support and the authors would like to thank for the financial support by Bureau of Energy, Ministry of Economy Affair of R.O.C. through grants 99-D0204-4, Aim for the Top university project of the Ministry of Education of the R.O.C. and YZU Fuel Cell Center through the grant No. 217019 and National Science Council of R.O.C. through the grant NSC 98-2627-M-155-003. The authors also like to thank Shuo Jen Lee, Chia Chieh Shen, Chuin Tih Yeh, Shih Hung Chan, Kuen Song Lin, S.D. Lin, Ay Su, Fangbor Weng, Guo Bin Jung of Yuan Ze University for their valuable advice and assistance in the experiments. In addition, we would like to thank the YZU Fuel Cell Center and NENS Common Lab, for providing access to their research facilities.

\section{References}

1. Minggu, L.J.; Daud, W.R.W.; Kassim, M.B. An overview of photocells and photoreactors for photoelectrochemical water splitting. Int. J. Hydrogen Energy 2010, 35, 5233-5244.

2. Kelly, N.A.; Gibson, T.L. Solar energy concentrating reactors for hydrogen production by photoelectrochemical water splitting. Int. J. Hydrogen Energy 2008, 33, 6420-6431.

3. Brunetto, C.; Moschetto, A.; Tina, G. PEM fuel cell testing by electrochemical impedance spectroscopy. Electric. Power Syst. Res. 2009, 79, 17-26.

4. Liu, P.; Zhu, R.; Que, R. A flexible flow sensor system and its, characteristics for fluid mechanics measurements. Sensors 2009, 9, 9533-9543.

5. Yang, Y.J.; Cheng, M.Y.; Chang, W.Y.; Tsao, L.C.; Yang, S.A.; Shih, W.P.; Chang, F.Y.; Chang, S.H.; Fan, K.C. An integrated flexible temperature and tactile sensing array using PI-copper films. Sens. Actuat. A 2008, 143, 143-145.

6. Chuang, H.S.; Wereley, S. Design, fabrication and characterization of a conducting PDMS for microheaters and temperature Sens. J. Micromech. Microeng. 2009, 19, 045010-045016.

7. Lee, C.Y.; Weng, F.B.; Cheng, C.H.; Shiu, H.R.; Jung, S.P.; Chang, W.C.; Chan, P.C.; Chen, W.T.; Lee, C.J. Use of flexible micro-temperature sensor to determine temperature in situ and to simulate a proton exchange membrane fuel cell. J. Power Sources 2011, 196, 228-234. 
8. García-Alonso, A.; Huizti, X.; Castaño, E.; Gracia, F.J. An optimized preparation process of stainless-steel substrates and their application to thin-film high pressure sensors. Sens. Actuat. A 1993, 37, 703-707.

9. Chang, S.P.; Allen, M.G. Demonstration for integrating capacitive pressure sensors with read-out circuitry on stainless steel substrate. Sens. Actuat. A 2004, 116, 195-204.

10. Jiang, L.; Wong, M.; Zohar, Y. A micro-channel heat sink with integrated temperature sensors for phase transition study. In Proceedings of 12th IEEE Int. Conference on Micro Electro Mechanical Systems, Orlando, FL, USA, January 1999; pp. 159-164.

11. Jiang, L.; Wong, M.; Zohar, Y. Phase change in microchannel heat sink with integrated temperature sensors J. Microelectromech. Syst. 1999, 8, 358-365.

12. Jiang, L.; Wong, M.; Zohar, Y. Transient temperature performance of an integrated micro-thermal system. J. Micromech. Microeng. 2000, 10, 466-476.

13. Jiang, L.; Wong, M.; Zohar, Y. Forced convection boiling in a microchannel heat sink. IEEE J. Microelectromech. Syst. 2001, 10, 80-87.

14. Shih, C.Y.; Chen, Y.; Li, W.; Xie, J.; He, Q.; Tai, Y.C. An integrated system for on-chip temperature gradient interaction chromatography. Sens. Actuat. A 2006, 127, 207-215.

15. Xiao, S.; Che, L.; Li, X.; Wang, Y. A cost-effective flexible MEMS technique for temperature sensing. Microelectr. J. 2007, 38, 360-364.

16. Bielska, S.; Sibinski, M.; Lukasik, A. Polymer temperature sensor for textronic applications. Mater. Sci. Eng. B 2009, 165, 50-52.

17. Lee, C.Y.; Lee, S.J.; Shen, C.C.; Chang, C.C.; Lin, C.H.; Yeh, C.T. Micro-sensors with novel micro-channels in a micro-reformer. Int. J. Hydrogen Energy 2010, 35, 10630-10634.

18. Uchiyama, S.; Ishigami, Y.; Ohta, M.; Niigaki, M.; Kan, H.; Nakanishi, Y.; Yamaguchi, T. Growth of AlN films by magnetron sputtering. J. Crystal Growth 1998, 189-190, 448-451.

19. Chung, G.S.; Kim, C.H. RTD characteristics for micro-thermal sensors. Microelect. J. 2008, 39, 1560-1563.

20. Zhang, K.L.; Chou, S.K.; Ang, S.S. Fabrication, modeling and testing of a thin film Au/Ti microheater. Int. J. Therm. Sci. 2007, 46, 580-588.

21. Weast, R.C. CRC Handbook of Chemistry and Physics, 64th ed.; CRC Press: Boca Raton, FL, USA, 1983.

(C) 2011 by the authors; licensee MDPI, Basel, Switzerland. This article is an open access article distributed under the terms and conditions of the Creative Commons Attribution license (http://creativecommons.org/licenses/by/3.0/). 